\title{
Interview with Gundula Jeschke
}

\section{Interview mit Gundula Jeschke}

\begin{abstract}
Today I am very pleased to present you an interview conducted with a very special personality in the field of metallography training in Germany: the longtime head of the Department of Metallography of the Lette Association Berlin, Gundula Jeschke.
\end{abstract}

Dear Mrs Jeschke, dear Gundula, how did you come to the world of metallography?

For me it was more a matter of chance and the same goes for many of those who graduated after me. After graduating from high school, I was not sure about whether I wanted to

study and which subject to study, though it had to be a subject within the natural sciences. At the time, the advisory service was rather meager and so it happened that I took a friend's advice and made my way to the Lette Association. As the young person I was, the general talk by the principal didn't inspire me and I was rather bored browsing the brochure on display. Then I found a reference to metallography training and I spontaneously decided to register. Never would I have thought this decision would be followed by almost 44 years of work in this profession.

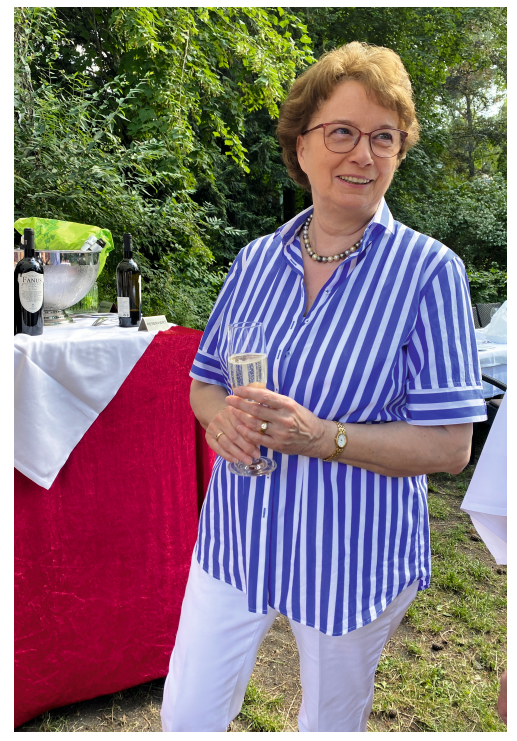

Fig. 1: Gundula Jeschke.

Bild 1: Gundula Jeschke.
Ich bin sehr froh, Ihnen heute ein Interview mit einer ganz besonderen Persönlichkeit der Metallographieausbildung in Deutschland vorstellen zu können - der langjährigen Leiterin der Metallographieabteilung des Lette Vereins Berlin, Gundula Jeschke.

Sehr geehrte Frau Jeschke, liebe Gundula, wie bist Du zur Metallographie gekommen?

Bei mir war es - wie auch bei vielen späteren Absolventinnen und Absolventen - eher Zufall. Nach dem Abitur wusste ich noch nicht so genau, ob und was ich studieren wollte, aber es sollte etwas „naturwissenschaftliches" sein. Die Beratungen waren damals eher dürftig und so kam es, dass ich den Tipp eines Freundes meines Vaters annahm und mich in den Lette Verein begab. Den allgemeinen Vortrag des Schulleiters fand ich als junger Mensch nicht inspirierend, den ausgelegten Prospekt blätterte ich eher gelangweilt durch. Dann entdeckte ich den Hinweis zur Ausbildung Metallographie und entschied spontan, mich dafür anzumelden. Nie hätte ich gedacht, dass daraus fast 44 Jahre in diesem Beruf folgen sollten. 


\section{What does metallography mean to you?}

The foundation was laid by Charlotte Wachau and Gesine Seidel, head of department and assistant in the Department of Metallography. They communicated the enjoyment experienced in this exciting job and made me aware that careful work and learning discipline are rewarded by very good results. From today's perspective, the material preparation was carried out using old-fashioned devices and preparation agents. However, the result was there. The beauty of the microstructures still fascinates me and, given a "trained eye", true works of art can be photographed.

\section{What would you consider your greatest professional success?}

Looking back on almost 44 years in the Lette Association Berlin, of course many special moments come to my mind. I started as a technical assistant, became a subject teacher, and was eventually appointed head of the department. I never would have imagined this career which was made possible by the promotion of many people involved. I guess the greatest professional success were the many discussions and negotiations with companies aiming at modernizing the technical standard of the devices and the laboratory equipment. Having few own resources, it was possible to create and fund a good learning environment for the students based on cooperating with manufacturers of metallographic devices, laboratory furniture, and microscopes and I would like to take this opportunity to express my sincere thanks!

What was your most exciting professional experience?

Two business trips to Asia. In the spring of 1981, after only a little more than three years of professional experience, a first trip took me to China. As a metallographer, I had the chance to attend Summer School in the Institute for Metal Research of the Academy

\section{Was bedeutet Dir die Metallographie?}

Den Grundstein legten Charlotte Wachau und Gesine Seidel, die Abteilungsleiterin und die Assistentin der Abteilung Metallographie. Sie vermittelten mir die Freude an dem spannenden Beruf und machten mir klar, dass mit sorgfältigem Arbeiten und diszipliniertem Lernen sehr gute Ergebnisse zu erzielen sind. Die Präparation von Werkstoffen wurde nach heutiger Sicht mit altertümlichen Geräten und Präparationsmitteln durchgeführt, das Ergebnis aber stimmte. Noch immer fasziniert mich die Schönheit der Gefügeausbildungen, mit dem „geschulten Auge“ können wahre Kunstwerke fotografiert werden.

\section{Was würdest Du als Deinen größten beruf- lichen Erfolg bezeichnen?}

Bei einem Rückblick auf fast 44 Jahre im Lette Verein Berlin fallen einem natürlich viele besondere Momente ein. Ich habe als technische Assistentin begonnen, wurde dann Fachlehrerin und schließlich Abteilungsleiterin. Ein Werdegang, den ich mir nie hätte vorstellen können und der durch die Förderung vieler Beteiligten möglich wurde. Der größte berufliche Erfolg waren wohl die vielen Gespräche und Verhandlungen mit Firmen, um den technischen Standard der Geräte und der Laboreinrichtungen zu modernisieren. Ein gutes Lernumfeld für die Schülerinnen und Schüler zu schaffen und mit wenig Eigenmitteln zu finanzieren, gelang durch das kooperative Mitwirken der Hersteller von metallographischen Geräten, Labormöbeln und Mikroskopen. Ihnen sage ich an dieser Stelle meinen herzlichen Dank!

\section{Was war Dein aufregendstes berufliches Erlebnis?}

Das waren zwei berufliche Reisen nach Asien. Die erste Reise im Frühjahr 1981 führte mich nach nur etwas mehr als drei Jahren Berufserfahrung nach China. Ich durfte als Metallographin an der Summer School im Institut für Metallforschung der Akademie der Wissen- 
of Sciences in Shenyang. Thus, being the only woman and youngest participant, I met and had to take a stand among, for instance, Prof. Petzow, Prof. Bühler, Prof. Hougardy, Dr. Elsner, Dr. Wellner, all of them men. An experience that provided me with more self-confidence! The second experience in Asia followed in the years 2001 and 2003 in the context of metallography courses at the Korea University of Technology Education in South Korea. I received an invitation from Prof. Kim, whom I had met in the Lette Association where, during his studies, he sat in on lectures.

\section{Which advice proved particularly help- ful in your professional career?}

It was an advice I didn't take. Dr. Ottow, head of the department at the time, suggested to me to work half days as a technical assistant in the Lette Association, thus being able to pursue "extra-professional" studies at the Technical University - and eventually becoming head of the department. Though the idea was tempting, I decided against it. I couldn't imagine being able to do a good and successful job in both activities. However, after all, it came to pass that I had been head of the Department of Metallography for thirteen years.

If you could be someone else for one day, who would you be?

I cannot state any names, but a profession having nothing to do with metallography: a hotel manager. I would love to have a look behind the scenes of a large or small hotel, discovering how everything is organized. When you are guest in a hotel, you just expect everything to be perfect: clean and comfortable rooms, good-tasting food, and staff complying with all your wishes without any grumbling. A certain resemblance with the school routine at the Lette Association cannot be denied. And I think my colleagues will probably agree with me. schaften in Shenyang teilnehmen. So lernte ich die Herren Prof. Petzow, Prof. Bühler, Prof. Hougardy, Dr. Elsner, Dr. Wellner u. a. kennen und musste mich als einzige Frau und jüngste Teilnehmerin behaupten. Ein Erlebnis, dass bei mir für weiteres Selbstvertrauen sorgte! Die zweite Asienerfahrung folgte in den Jahren 2001 und 2003 mit Metallographie Kursen an der Korea University of Technology Education in Süd-Korea. Eingeladen hatte Herr Prof. Kim, den ich im Lette Verein kennengelernt hatte, wo er während seiner Studienzeit hospitierte.

\section{Welcher Rat war für Deine berufliche Kar- riere besonders hilfreich?}

Einen Rat, den ich nicht angenommen habe. Mir wurde von dem damaligen Abteilungsleiter Herrn Dr. Ottow vorgeschlagen, halbtags als Technische Assistentin bei Lette zu arbeiten und so „nebenbei“ an der TU zu studieren - dann können Sie einmal die Abteilungsleitung übernehmen. Das hörte sich zwar verlockend an, aber ich entschied mich dagegen. Beides gleich gut und erfolgreich zu machen, das konnte ich mir nicht vorstellen. Es sollte dann doch dazu kommen, dass ich die Abteilung Metallographie dreizehn Jahren leiten durfte.

\section{Wenn Du für einen Tag jemand anderes sein könntest, wer wäre das?}

Hier kann ich keinen Namen nennen, sondern nur einen Beruf, der nichts mit Metallographie zu tun hat: Hotelmanagerin. Gerne würde ich hinter die Kulissen eines großen oder kleinen Hotels schauen und sehen, wie alles organisiert wird. Als Hotelgast erwartet man, dass alles perfekt läuft, die Zimmer sauber und komfortabel sind, das Essen schmeckt und einem jeder Wunsch ohne Murren erfüllt wird. Eine gewisse Ähnlichkeit mit dem Schulalltag bei Lette ist unverkennbar, da werden mir meine ehemaligen Kolleginnen und Kollegen wahrscheinlich zustimmen. 
If you could meet a historical or virtual personality, who would it be?

There are many. However, I would have really liked to meet Viktor von Bülow, better known as Loriot. His sketches are inspired from real life, they hurt nobody, and come with a profound sense of humor. I consider it a blessing when compared to many present day "comedians" who don't make me laugh. But maybe this is just an age-related issue. The farewell gift offered by my former colleagues at the Lette Association was a video with the plot based on Loriot's sketch "Winning the lottery". Incredibly funny and well done. It will always remind me of the great time spent together at work!

\section{Which was your parents influence on you?}

I had a harmonious childhood and luckily did not experience any major problems. My parents were living examples teaching me lessons on how to lead a successful life. Nonexcessive ambition, reliability, punctuality, and empathy for our fellow human beings. Not everything at once and immediately: first the focus on high school graduation, then we will pay for the driving license - something I failed to understand at the time. These and similar experiences influenced me and helped me in my professional life.

\section{What have you been inspired by?}

During the many years of training young people, many things have changed, unfortunately not always for the better. Not all students demonstrate the attitude towards "learning" or are committed to it. Today, it is pointed out that there is a lack of academic knowledge, especially by companies providing dual training. My colleagues had to make the same observation. It was a source of motivation for me to nevertheless find a way to motivate the young people and prepare them for working life. Many face-to-face talks and the search for solutions for various problems made up a large part of my work. The reward for all of this is a great deal of

\section{Wenn Du eine historische oder virtuelle Per- sönlichkeit treffen könntest, wer wäre es?}

Da gibt es viele, aber sehr gerne hätte ich Viktor von Bülow getroffen, besser bekannt als Loriot. Seine Sketche sind aus dem Leben gegriffen, verletzen niemanden und haben einen tiefgründigen Humor. Eine Wohltat gegenüber vielen heutigen „Comedians“, über die ich nicht lachen kann - das ist vielleicht auch eine Altersfrage. Meine ehemaligen Mitarbeiter haben mir zum Abschied vom Lette Verein ein Video geschenkt, dass den Loriot Sketch "Lottogewinn" zum Vorbild hat. Unfassbar lustig und gut gemacht, es wird mich immer wieder an die schöne gemeinsame berufliche Zeit erinnern!

\section{Wie hat Dein Elternhaus Dich geprägt?}

Meine Kindheit verlief harmonisch und zum Glück ohne große Probleme. Meine Eltern haben mir alles Nötige für ein erfolgreiches Leben vorgelebt. Einen nicht übertriebenen Ehrgeiz, Zuverlässigkeit, Pünktlichkeit und Empathie für die Mitmenschen. Nicht alles auf einmal und sofort - erst die Konzentration auf das Abitur, dann finanzieren wir den Führerschein - dafür hatte ich damals kein Verständnis. Diese und ähnliche Erfahrungen haben mich aber geprägt und mir im beruflichen Alltag geholfen.

\section{Wovon hast Du Dich inspirieren lassen?}

In den vielen Jahren in der Ausbildung von jungen Menschen hat sich sehr viel verändert, leider nicht immer zum Positiven. Die Einstellung und das Engagement zum „Lernen" sind nicht bei allen Schülerinnen und Schülern vorhanden. Heute wird, besonders von dualen Ausbildungsbetrieben, auf die mangelnden schulischen Kenntnisse hingewiesen. Diese Feststellung haben meine Kolleginnen und Kollegen auch machen müssen. Trotzdem einen Weg zu finden, die jungen Menschen zu motivieren und auf das Berufsleben vorzubereiten, war für mich immer Ansporn. Viele persönliche Gespräche und das Suchen nach Lösungen für die unterschiedlichsten Proble- 
positive feedback from former students who made their way in their professional and private lives.

\section{What do you associate with the Practical Metallography?}

As a matter of fact, the journal Practical Metallography was always available to me. While still a student, I could browse it without really understanding much of its content. However, I liked the beautiful micrographs. Later, I eventually (mostly) understood the content of the articles and it was fascinating to monitor the journal's evolution throughout the years. As a member of the editorial board, I witnessed the dedication to interesting manuscripts and I can only encourage the metallography community to submit articles with a practical focus.

Dear Gundula, thank you so much for this interesting and impressive interview which will surely particularly touch and inspire our readers. Speaking also on behalf of the entire Practical Metallography editorial team, I would like to wish you all the best for your future endeavours.

Frank Mücklich, publisher of the Practical Metallography me machten einen großen Teil meiner Arbeit aus. Der Lohn dafür ist, viele positive Rückmeldungen von Ehemaligen zu erhalten, die ihren Weg im Beruf und Leben gefunden haben.

\section{Was verbindet Dich mit unserer Prakti- schen Metallographie?}

Die Zeitschrift Praktische Metallographie war für mich eigentlich immer da. Schon als Schülerin konnte ich in ihr blättern - ohne allzu viel zu verstehen, die schönen Gefügebilder allerdings gefielen mir. Später verstand auch ich dann (meistens) den Inhalt der Artikel und es war spannend mitzuerleben, wie sich die Zeitschrift im Laufe der Jahre entwickelt hat. Als Mitglied des Editorial Boards habe ich die Bemühungen um interessante Manuskripte miterlebt und kann die metallographische Community nur ermuntern, praxisnahe Beiträge einzureichen.

Liebe Gundula, ich danke Dir ganz herzlich für dieses interessante und eindrucksvolle Interview, das unsere Leserinnen und Leser ganz sicher besonders berühren und auch inspirieren wird. Ich wünsche Dir - auch im Namen der gesamten Redaktion der Praktischen Metallographie - alles Gute für Deine Zukunft.

Frank Mücklich,

Herausgeber der Praktischen Metallographie

\section{Bibliography}

DOI 10.1515/pm-2021-0051

Pract. Metallogr. 58 (2021) 9; page 605-609
(C) 2021 Walter de Gruyter $\mathrm{GmbH}$,

Berlin/Boston, Germany

ISSN 0032-678X · e-ISSN 2195-8599 